\title{
Study on the Role of College Students in Learning and Practicing Socialist Core Values
}

\author{
Shuzhi Yao ${ }^{1, a}$, Yiyu $\mathrm{Wu}^{2, \mathrm{~b}}$ \\ ${ }^{1}$ Shaanxi University of Science \& Technology, Xi'an, Shaanxi, 710021 \\ a email, ${ }^{b}$ email
}

Keywords: Students; Socialist Core Values; Learning; Practice

\begin{abstract}
General Secretary Xi Jinping put forward the "three levels to promote" socialist core values at the 18th Party Congress of the party, has aroused strong repercussions in the whole society, all walks of life set off a wave of research. Students as builders and successors of the socialist cause, but also actively involved in it. But the lack of thinking and practice in the learning process, a vague position, so that did not achieve the desired results. This paper begins research status, clarify the role of the position of contemporary college students, specifically targeting college students in the learning and practice of socialist core values..
\end{abstract}

\section{Introduction}

Socialist core values are the rudder dream life struggle, calcium spirit of the Chinese nation, but also the life of college students' first grain buttons. " (Speech by Xi Jinping fifty-four can add standard). "About the cultivation and practice of socialist core values of opinion" (General Office of the CPC Central Committee issued in December 2013, later referred to as "Opinion") that: should cultivate and practice the socialist core values into the whole process of national education efforts cultivating moral, intellectual, physical, and aesthetic development of socialist builders and successors [1].

"Young people are leading the new trend of social forces." [2] (excerpt from the original speech Xi Jinping on Youth Day 2013) College Students Youth has always been one of the main social groups most dynamic in various social activities It plays a dominant role. Students how to tap and play their own value in the study and practice the socialist core values, clear roles, clear direction, contemporary college students will be able to single-minded, high efficiency, engaged in socialist core values of learning and practice them, Students play their own value.

\section{Clarify Learners Roles and Make Socialist Core Values of Theoretical Knowledge}

Students clearly the primary identity of the learner, is committed to the study and practice of socialist core values preconditions. "Contemporary College Students' Values issue is not only the personal life thinking and positioning, but related to a country's development and future" [3] only strengthen the socialist core values of the profound meaning of learning, into the inner spiritual power, in order to arm the mind.

"Opinions" that:. "The party's 18 put forward the socialist core values and requirements of the development of Socialism with Chinese characteristics fit with the Chinese traditional culture and the outstanding achievements of human civilization to undertake phase, we unite the whole party and the social value important conclusion made by consensus. "This shows that strengthen the Chinese traditional culture of learning, understanding of socialist core values is very necessary. Students are at the best period of life receive the knowledge, but also the "Three Views" stereotype formed a crucial stage, the initiative to strengthen the excellent cultural knowledge to learn, not only enhance their own internal training, but also the socialist core values of understanding and adaptation. Socialist core values and traditional Chinese cultural essence an unbroken, both condensation Confucian "benevolence" Thought Mohists "universal love" thinking, but also absorbed the legalists "Law" Thought and the Taoist "charity," and many other excellent ideas, However, in essence, it is a kind of human thinking caused by the transformation of moral 
education. Xi Jinping pointed out: "the core values, is actually a German, both personal and Germany, but also a Dade is Germany, the German society of non-German national fashion, people can not stand without virtue.." [4] Since ancient times, since each school emphasized moral education culture in the field of social Juche idea, has paid attention to the small German private morality education, but also pay attention Dade education. As a higher cultural awareness of contemporary college students, the ideological and moral orientation is often a social ideological and moral benchmark, so the college students take the initiative to strengthen the Chinese traditional culture of learning, which absorb the essence of the socialist core values at all levels of the advocacy there will be more profound cultural connotation of insight and experience.

Socialist core values of socialism with Chinese characteristics based on the development environment, the theoretical system of socialism Chinese characteristics is its guiding ideology. Reform and opening up and developing the socialist market economy ideology appeared pluralistic changing characteristics, ideological and cultural exchanges worldwide clash of values formed under the new situation blending compete, thinking of college students in a sensitive period of the intersection. Students need to take the initiative to face this new contemporary issues, and take responsibility of the times, actively strengthen the party's basic theoretical knowledge of learning, especially for the basic tenets of Marxism to deepen understanding, but also to deepen the study of the real situation observed, socialism will learn core values and living closely together, solidly grasp the basic theory of the party's intension to understand the core values of socialism, "three levels advocated" theory origin, understand the basic laws of social development, a clear development mission, struggle to establish confidence, and transformed into its strong spiritual power. Students strengthen basic theoretical knowledge of the party to form a systematic system of values in mind, the inherent logic of the relationship between the state, society, the individual level there are three more to think and to further strengthen summarized, the socialist core values its contents must not be limited to "three advocates", there is a vast space and ample room for research and development.

General Secretary Xi Jinping said that "innovation is the soul of a nation's progress, is an inexhaustible source of prosperity of a country is the Chinese nation's deepest talent." [5] in order for the message to young people. Changes in current social development, people's way of thinking also changed, college students are the most sensitive to exposure to new things social groups. Electronics, networking, information technology, digital era, social rhythm of life rapidly improve, the traditional such as newspapers, books and other information passed to obtain route is gradually being replaced by microblogging, letters and other new media channels, students should take advantage of these platforms, serious seize the moment and use this popular way of thinking. Students should possess this spirit of innovation, insight into current social learning and innovative thinking, full use of the network and online "store" and offline combination of the socialist core values into their daily lives to promote its clothing, food, live, line fields, so that the audience understand the core values of socialism from the visual, auditory, tactile and other multi-directional sensing. By orchestrating drama, dance, comedy, comic and other cultural programs, or integrated into the local cultural characteristics which form (such as opera, Shaanxi Opera, Kunqu Opera and other species), the socialist core values loved by the masses of people, willing to accept the way of thinking presented, to promote its socialist core values. A certain way of thinking is a product of the era of social development, strengthen the college students learn creative thinking, not only leading the college students participate in socialist core values of learning and advocacy, and leading the whole social groups involved in the learning atmosphere of socialist core values among.

\section{Clarify Practitioner Role, Promote the Socialist Core Values into Life and Serve The People}

General Secretary Xi Jinping had a cordial message to young people: the majority of young people to remember "empty talk, hard work and prosperous," based on their own, work hard, start from their own, from scratch, with industrious hands, first-class performance achievements belong his wonderful life. [6] Students practice a clear role, it is to the benefit of the study of socialist core values of life, to serve the real demands of life. Students should be promoted through the practice of socialist core values popular, daily life, it is applied to life, to serve life, to guide and promote the 
formation of universal values, identity, intimacy.

Direct experience with the first impression comes from the most basic life practice, practice is the university student life and social reality the most direct means of communication, is at the forefront of Social Watch "post." Education should pay attention to student life practice and direct experience thus obtained, deepen practical activities of life in the socialist core values of recognition and understanding, and internalized as self-cultivation. Students should do in life practice positive activists and thinkers seriously, the socialist core values are widely used among the living, to form a correct judgment standard by the socialist core values, for the things in life to do the right judgments development trend ; Students should do in life practice the socialist core values practitioner, advocate, through the socialist core values of understanding, correctly handle the relationship between good interpersonal communication, straighten out the good personal relationship between the collective and do social ism core values spokesperson; Students should actively do the socialist core values guardian in life practice the socialist core values to life through the words and deeds, correctly identify the phenomenon of life in all activities undermine the socialist core values, damage national interest and other illegal acts, the courage to confront and combat it, and promote the healthy growth of the students themselves through a variety of ways.

Students combine their theoretical level and the empirical experience, from different angles, orientation, thinking to observe and interpret the socialist core values, we will come to a different interpretation of results. Students' main task is to practical learning, learning is a dynamic process of practice, that is, to explore new knowledge, consolidate the basic knowledge test a procedure "old" knowledge, and college students playing the role of the body in the whole learning process of practice, decisions the width and depth of learning content. Students in the learning practice within the College can take advantage of external educational resources and education platform, the socialist core values were Connotations, form their own opinions and internalized as spiritual power. Students study and practice of today is no longer confined to raise self-centered, began to focus on community features. Students expand knowledge through study and practice exchange level, change the identity of the recipient of knowledge under the traditional concept of gradual transition to a knowledge-transfer and promote the identity of persons.

Social work practice to examine contemporary college students is important to understand the true extent of the socialist core values and application level. Modern students are highly personalized and full of thought over a social group, can make full use of structures from the Universities of summer, winter social practice platform, and actively looking for ways to work practices (such as social work; entrepreneurship, etc.), the concept of socialist core values subtle work in practice. Theory is a view of universal significance, and social practices tend to highlight the main character, a good theory of how to guide social practice and in particular into the general theory of practice which requires extensive Students participate in practical activities, deepen their understanding of the theory understanding and recognition, sublimation and perfect. Socialist core values vitality condenses on the practice of social work practice activity among college students as a learning and practice the socialist core values of the main force, through in-depth social work practice, social way of thinking to understand your audience, using the socialist core values of social services, improve self-awareness, and increase their abilities through work practices, enhance social responsibility.

In , students are set in one of the study and practice of active social subjects, social atmosphere is leading an important social force. Students learn to play and practice the socialist core values of enthusiasm, initiative, and self-learners clear, the practice of the role, learning to fully use innovative ways of thinking, to promote the popularization of the socialist core values, life, universal, promoting social interpretation and development of Marxism core values connotation. General Secretary Xi Jinping said that "the National Youth Xing Xing, youth are strong, the country is strong." [7], (taken from the 2013 Youth Day speech on May Fourth Movement) in the majority of college students do a good job positioning the same time, correct attitude, the courage to assume social responsibility, practice the "studious, virtue, discernment, probity," the basic requirements in the study and practice for the popularization and development of the socialist core values of 
dedication to its power force.

\section{References}

[1] CPC Central Committee issued "on the cultivation and practice the socialist core values views" [J]. 2011 Sound level (1).

[2], [5], [6], [7] Xi Jinping. Speech [J]. when the discussion with all the outstanding young representatives of the Chinese National Education .2013 (6).

[3] Guo Wei. Contemporary Students' Attitude and Education Research [G]. Northeast Normal University. 2007, 05, 01.

[4] Xi Jinping. Youth should consciously practice the socialist core values - On the teachers and students of Beijing University Speech at the Forum [N]. 2014-05-01 People's Daily (1). 